\title{
EDITORIAL
}

\section{Reflections of a country plastic surgeon}

$\mathrm{O}$ ne of the great things about being a country plastic surgeon in a small city in Ontario is that there are so many operations to perform; the problem is how to get enough operating time.

One of the negative things is the system, which works on a budget regardless of the amount of work. So, to not overspend on the budget, patients have longer wait times or go to other hospitals where the budget is bigger. Anyway, my resolution is not to discuss religion, politics or Medicare - in Canada, that is the same thing. Despite my resolution, I have to say something when patients ask me, "Why can't I have my basal cell treated now?"; I say, "I have the time, the hospital does not. They have to meet their budget". Amazingly, most Canadians accept this; a far cry from the independent 'outback' personalities I grew up with as a child - "Nobody tells me what to plant!"

On the other hand, maybe I have misjudged Canadians. There is a strong streak in people here that to actually pay for something when you could get it free would be the height of foolishness, and these people are canny! Free trumps right away any time.

There is the occasional mild complaining, but nobody ever does anything about it.

Country people are tough and stoic, and are proud of it. To work in the country, the plastic surgeon needs to be bilingual, and add 'country talk' to 'city talk'. Patients here are down to earth and accepting, but you have to be able to sum it up quickly and to the point; no fancy double talk or complex informed consents. They already know what could go wrong. To tell them is insulting. You just say what they need and why. They already know anyway because their general practitioner told them. Many even come to the first visit thinking you are going to operate on the spot without having seen them first because their general practitioner has decided what operation they need.

If you have a ear for it, it is possible to speak the local dialect if you keep your ears open and enjoy.

Things I have heard are the following: irony-deficient anemia, quite a wee while, umbrella 30, mammeogram, gangrion and gangilon, chicken pops, chyriopractor and chiorpractor. Some others are the following, "Hello, what do you know? Nothing, what do you know?" Forget the difference between few and less; good and well. Those are gone forever, even on CBC.

Now it's right to first names and, 'I put some Dettol on'er, Doc and

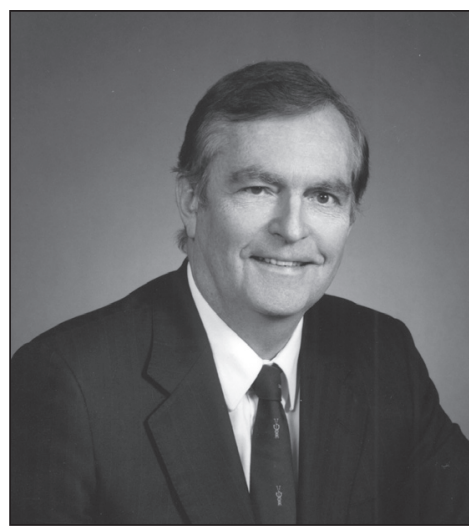
she healed up real good".

When I see people in ambulatory care, many people prefer to call it ambletory care, and so do I. Talking to teens who bash their hands on concrete walls in a testosterone fit is easy. Just do it like a TV hockey interview. And drop your 'g's'. It's 'goin' not 'going'. How about the following: "The doc put a splinter on it and I just got X-rated". My theory is that people know how to speak properly, but talking country is just a lot funnier and that's why they do it.

Having a country plastic surgery practice means patients are stoic and accepting. You can perform many surgeries under local anesthesia; patients love the idea of not being 'put out' and having a 'double double' before surgery. For nonCanadians, that means a gigantic coffee with lots of sugar enough to cause diabetes.

Although, there is one problem, and that is getting more operating time without being labelled a 'whistle blower'.

Country people will wait and never criticize the system they have come to love; the question is how long a wait is too long?

John R Taylor 